\title{
RUSSIA'S TROJAN HORSE IN EUROPE? ITALY AND THE WAR IN GEORGIA
}

\author{
Maurizio Carbone
}

In August 2008, Georgia launched a large-scale attack to retake control of South Ossetia, an enclave in the northern part of its territory that had been trying to break away formally since the late 1980s. In response, Russia bombed not only military but also civilian targets, claiming that its intervention was meant to protect Russian citizens. This quick escalation of events raised concerns about other unresolved conflicts in the South Caucasus. In fact, within a few days, Russian troops took control of South Ossetia and were ready to start a second front in Abkhazia, another separatist area within Georgia.

Various world leaders and international organizations tried to find a solution to end the war. The UN Security Council met on a number of occasions, but failed to adopt a resolution. One of the most decisive actors was the European Union (EU), which, under the leadership of the French presidency, first managed to get a ceasefire and then applied soft sanctions on Russia that eventually led Russia to withdraw from the Georgian territory. As in other cases, the EU was divided. On one side, a group of member states in Central and Eastern Europe, together with the United Kingdom and Sweden, wanted the EU to take a tough stance against Russia. On the other side, a group of member states in Western Europe promoted a conciliatory approach with a view to avoid antagonizing Russia. Italy was in this group, but its position was seen as too close to Russia's claims. Nevertheless, in spite of the significant divergences among its member states, the 
European Union this time acted as a unified entity and was central to resolving the crisis.

This chapter analyzes the war in Georgia from the Italian foreign policy point of view. The first section briefly introduces the politics of the South Caucasus (which comprises Georgia, Armenia, and Azerbaijan), looking at the roles played by internal and external actors. The next section sketches the evolution of the relations between Italy and Russia over the past two decades. The following two sections analyze the development of the war, focusing on the initiatives taken by the EU and by Italy. The two sections that follow interpret the effects of the war in Georgia on Italy's foreign policy carried out by the new centerright government. The conventional view is that Italy's position can be explained by the personal relationship between its prime minister, Silvio Berlusconi, and Russia's prime minister (and former president), Vladimir Putin. While this may be true, it should not be forgotten that the various center-left governments during the 1990s and in the mid-2000s also carried out a pro-Russia policy. The bipartisan foreign policy experienced in the case of the war in Georgia, therefore, is not so much a consequence of the simplified political system generated by the April 2008 elections. Rather, it is the outcome of a pragmatic foreign policy that saw, in the common approach at the EU level, the best way to pursue Italy's economic interests. This pragmatic foreign policy implies, at times, raising the profile of the EU in the international arena and, at other times, undermining it, especially when Italy's economic interests are at risk.

\section{The Unstable South Caucasus}

The collapse of the Soviet Union was apparently a peaceful event, giving rise to the creation of 15 states. It also resulted in a number of territorial disputes, which in a few cases ended up in wars. Ceasefire agreements were signed in all cases, thanks to negotiations led by various international players. From this situation, four de facto states emerged, two of which, Abkhazia and South Ossetia, are inside Georgia. ${ }^{1}$ In November 1989, local authorities decided unilaterally to declare South Ossetia an autonomous republic, to secede from Georgia, and to form a single entity with North Ossetia, which is located in Russia. The Georgian Supreme Soviet dismissed the declaration of independence as unconstitutional and eventually abolished South Ossetia's autonomy. Troops sent to the region met with resistance from the local population and supporters coming from North Ossetia and other parts of the Russian Federation. A ceasefire was signed in May 1992, but soon after the 
South Ossetian Parliament adopted a declaration of independence. In July 2002, local authorities in Abkhazia announced that they wanted to become a sovereign state, to be loosely associated with Georgia. In response to the restriction of its autonomy by the Georgian authorities, they started a war. In this case as well, Georgia sent its troops to fight against the Abkhaz forces, which meanwhile had received support from numerous volunteers coming from Russia. The Abkhaz militias won the war, and a ceasefire was signed in December 1993, which resulted in a de facto independence. Maintaining peace in the two separatist areas was extremely difficult. International mediators supported the establishment of loose federal solutions, although they were not accepted by all parties. ${ }^{2}$

The status of South Ossetia and Abkhazia is central to the evolution of the relationship between Georgia and Russia. Russian involvement in peacekeeping operations has been controversial. In fact, Georgia has accused Russia of encouraging the independence of the two separatist states, with the eventual aim of annexing them. Russia, of course, has denied these accusations, although it has distributed Russian passports to the local population. Following the Rose Revolution in 2003, the new Georgian president, Mikheil Saakashvili, adopted a pro-West agenda, trying to distance himself from Russia and taking a hard line on South Ossetia and Abkhazia. Saakashvili has been supported by the West, particularly the US and the EU. Following the aid fatigue of the previous decade, the early 2000 s were characterized by a surge in economic assistance. The US has supported the Georgian government with financial and military means and has become the main sponsor for Georgia's and Ukraine's application to NATO membership. The visit of George W. Bush in May 2005, the first by a US president, marked the seal of approval of the Georgian desire "to join the West."3 This direct support to Georgia, together with the fact that the US supported Kosovo's independence and planned to build missile defense facilities in Poland and the Czech Republic, annoyed Russia.

Another important factor in the growing tensions between Georgia and Russia is the geographical location of Georgia, which is the only country in the region with access to the open sea. The project to link Europe and Asia, bypassing Russia, makes Georgia a competitor with Russia for the transit of Caspian Sea and Central Asia resources. More generally, in many sections of Russian society there seems to be a sort of "imperial nostalgia," which considers all of the former Soviet territories to fall within Russia's sphere of influence. ${ }^{4}$

Problems of stability in Georgia and in the whole Caucasus have important implications for the European Union, not least because of its geographic proximity as a result of the 2004 and 2007 enlargement 
rounds. Energy dependence represents a central concern behind the EU's interest in stabilizing the region. The EU buys a quarter of its gas from Russia, and diversifying its sources has increasingly become a necessity. Georgia is included in the European Neighbourhood Policy (ENP), which was adopted by the EU with the aim to promote a zone of "prosperity, stability and security" at its borders. The EU has tried to be involved in resolving conflicts that are all but frozen. Seen from Brussels, stability in the South Caucasus implies fostering larger autonomy for the region and freedom from excessive meddling by neighboring powers. On the one hand, the EU has urged Russia to remain committed to the principle of Georgia's full sovereignty on its territory. On other hand, it has rejected the use of force as a means of preserving Georgia's territorial integrity. Unlike the US, and under pressure from Germany and Italy, the imperative has been not to antagonize Russia. As a result of these divisions, the EU has put its "weight behind negotiations mediated by the UN and OSCE." 5

\section{The Evolving Italy-Russia Relations}

Following the dissolution of the Soviet Union, Italy and Russia began negotiations for a friendship agreement. The economic dimension was central from the beginning. In fact, trade and investment between the two countries have progressively increased, and Italy has become one of Russia's privileged partners. The most important area of cooperation is in the field of energy, with a major role played by Eni SpA, the Italian multinational oil and gas company. Military cooperation is also significant, but it is Italy's heavy dependence on Russia's gas and oil that over the years has affected its policy toward Russia. The visit to Moscow in November 1992 by Emilio Colombo, the minister of foreign affairs, began a process that culminated in the Treaty on Friendship and Cooperation, signed in 1994 by Berlusconi. Interestingly, on that occasion the economic aspect of this relationship was accompanied by an ideological dimension: for the center-right, it was "right" to help Russia recover from the negative experience of the Communist regime. The G7 summit in Naples marked the beginning of what has become known as the "bridge approach": Italy would commit to support Russia's transition and sponsor its integration into the West, and in return it would receive increased investment and economic opportunities in Russia. The first Berlusconi government lasted less than a year, but the consolidation of a special relationship with Russia continued under the various center-left governments for the rest of the 1990s, although this approach was put at risk by the assertiveness of Putin's 
foreign policy. Both the center-right and center-left governments used similar tools: frequent high-level meetings between political leaders, increased projects for cultural exchanges, and aid from the business sector, particularly in the attempt to clone the Italian industrial district model in Russia. Neither coalition paid attention to sensitive issues, such as, for example, the protection of human rights and the worsening of democracy. ${ }^{6}$

Between 2001 and 2006, the Berlusconi government was probably the closest ally of Russia in the West. The most visible outcome of this special relationship was the establishment of the NATO-Russia Council, signed at a summit in Pratica di Mare (near Rome) in May 2002. The role played by Italy was controversial. Some argued that although the merit for establishing the council could not be attributed solely to Italy, despite what Berlusconi claimed, its contribution was still significant, together with that of Germany and the United Kingdom. ${ }^{7}$ Others argued that the decision had already been made elsewhere (i.e., in Texas between Bush and Putin) and that holding the meeting in Italy was part of Berlusconi's "catering diplomacy." Another important issue concerns the relationship between the EU and Russia, which Berlusconi made one of the main objectives of Italy's presidency of the European Union in the second half of 2002. Berlusconi and Romano Prodi, then president of the European Commission, did not share the same view: on various occasions, the former hinted at a possible accession of Russia in the EU, while the latter was against it, due to Russia's poor record on human rights and democratic practices. For Christian Collina, "Berlusconi interpreted an original sort of 'idealist' pragmatism that mixed post-Cold War optimism on transition and the need to engage Russia in Europe for reciprocal benefits; Prodi instead articulated a typical European normative approach, according to which a country was required to meet certain standards in order to be considered as a member or partner."

However, Berlusconi failed to understand that Russia was not interested in joining the EU because "it was not willing to sacrifice its sovereignty and status as a Eurasian great power." 10 In fact, Putin privileged establishing bilateral relationships with a number of countries in Europe, particularly Italy and Germany. ${ }^{11}$ Finally, Berlusconi's excessive defense of Putin occasioned a diplomatic blunder. During the presidency of the EU, the Italian prime minister claimed that Russia's alleged human rights abuses in Chechnya were made up by the press and by certain representatives of governments and international organizations. This declaration provoked a negative reaction from various EU leaders, who immediately stated that the Italian presidency did not represent the EU's view on the issue. This was an absolute novelty in 
EU practices. Similarly, the European Parliament, which had adopted various resolutions on human rights in Chechnya and on democracy in Russia, publicly criticized the behavior of the Italian presidency. ${ }^{12}$

The Prodi government, between 2006 and 2008, maintained the same pragmatic approach, based on the protection of economic interests and non-interference in political issues. The concerns that Prodi, as president of the European Commission, had expressed about Putin's dubious practices in Chechnya failed to materialize when he headed the center-left government. In fact, in March 2007, the two signed a number of agreements related to the energy, culture, military, and banking sectors. Interestingly, when during the press conference Prodi was asked whether Russia could eventually join the EU, he confirmed his skepticism..$^{13}$ The Prodi government, moreover, irritated Russia when it recognized the independence of Kosovo. Massimo D'Alema, then minister of foreign affairs, justified this action in the name of the "national interest," which he defined, however, in technical terms as protecting Italy's military staff in the region. For Osvaldo Croci, this was more likely a political decision, given Italy's "perceived need to align itself ... with the United States and the three major EU players (the United Kingdom, France and Germany), which have all announced their intention of recognizing the new state." 14

\section{The Outbreak of the War}

Following skirmishes that had occurred for more than two years, during the night between 7 and 8 August 2008, Georgia began an attack on Tskhinvali, the breakaway capital of South Ossetia. The separatist administration made claims that more than 2,000 people were killed, although only 100 deaths could be independently confirmed. ${ }^{15}$ In response, Russia launched large-scale air attacks, with the aim of defending citizens with a Russian passport. Military but also civilian targets were hit in various cities of Georgia proper. Soon after, Russia sent over 6,000 troops into Abkhazia. Russia was determined to show all former Soviet Union countries aspiring to join NATO that it was the only "security guarantor" in the region. The international community (many world leaders were in Beijing for the opening of the Olympic Games) criticized Russia. The United Nations Security Council (UNSC) met daily, but despite the pressure of the other members of the UNSC, Russia and China blocked any resolution on this issue. The US, partially paralyzed by the election campaign for the presidency, initially adopted a low profile and was willing for the EU to take the lead. President Bush, Secretary of State Condoleezza Rice, and Vice-President 
Dick Cheney condemned Russia's “dangerous and disproportionate” reaction and defended Georgia's territorial integrity. ${ }^{16}$

The European Union, under the leadership of the French president, Nicolas Sarkozy, played a significant role in finding a solution to the crisis. Of course, there were differences among its member states. A first group (Poland, Latvia, Lithuania, and Estonia), fearing the rise of an "imperialist" Russia, called on the presidency to immediately convene an extraordinary European Council, with the aim of adopting a tough stance on Russia. ${ }^{17}$ As this did not happen, the presidents of these four countries, together with the president of Ukraine, flew to Tbilisi to demonstrate their solidarity with Georgia and its president in a public rally. A second group of member states (Germany, Portugal, Greece, and Spain) did not want to blame Russia openly and wanted the EU to act as mediator between the two parties. ${ }^{18}$ Italy was among this group, although the words of its minister of foreign affairs, Franco Frattini, showed that it had taken sides: "Italy believes that it is not possible to form an anti-Russian European coalition, and in this we are close to Putin's position. However, Moscow must understand that peacekeeping operations, which today are carried out exclusively by its military forces, will need to be discussed with the international community." 19 The EU's diplomatic efforts culminated in the adoption of a peace plan, which was signed on 12 August, first by Russia's president, Dmitry Medvedev, and then by Saakashvili. The six-point plan included an immediate ceasefire of hostilities, full respect for the sovereignty and territorial integrity of Georgia, and the re-establishment of the situation that existed before the conflict. The two parties remained divided over the status of South Ossetia and Abkhazia and the deployment of international peacekeepers in the region. Georgia did not want its territorial integrity to be questioned. Russia, by contrast, claimed that the two de facto states had the right of self-determination and that Russian peacekeepers would remain to perform their duties. ${ }^{20}$

The NATO meeting on 19-20 August was another battleground, this time with an added transatlantic dimension..$^{21}$ The US proposed to review and possibly suspend all cooperative activities with Russia. A number of European states-particularly France, Germany, and Italycontested this confrontational approach. The solution was a skewed compromise. NATO expressed serious concerns for Russia's “disproportionate retaliation" in Georgia; decided to suspend the NATO-Russia Council, to the great disappointment of Italy; and agreed to set up a new forum, the NATO-Georgia Commission, to strengthen its relations with Georgia, which mainly involved training and equipping the Georgian army. The question of membership for Georgia and Ukraine, however, was postponed to a later meeting. It should be added that several 
countries, including the US, Poland, and the Baltic states, strongly supported the view that Ukraine and Georgia needed to be given something concrete before the next NATO meeting. This would not only address the new assertiveness of Russia in the region but also help strengthen democracy in those countries. The usual suspects expressed serious concerns about the potential negative implications for the alliance. The major fear was that of being dragged into war, if either Georgia or Ukraine should become involved in a conflict with Russia.

\section{Between Cold War and Appeasement}

Despite the agreed-upon peace plan with the EU, Russia was slow in withdrawing its troops from Georgia. The hawkish member states once again started putting pressure on the French presidency to convene an extraordinary European Council. ${ }^{22}$ Furthermore, on 26 August, Russia decided to recognize formally the independence of South Ossetia and Abkhazia. The French presidency immediately issued a statement on behalf of the European Union, declaring that Russia's recognition of the two separatist states was contrary to the principles of sovereignty and the territorial integrity of Georgia and would have serious consequences on EU-Russia relations. This decision caused a partial change in the dynamics within the European Union. France and Germany hardened their views on Russia, while Italy remained the only major country that continued to make the case against isolating Russia.

Contrary to what had happened during the war in Iraq in 2003, the summoning of the extraordinary European Council on 1 September 2008 produced positive results. This time, the European Union achieved a unitary position, with the conciliatory group managing to "tame" the demands of the hawkish group. The decision was not to antagonize Russia, which could have provoked serious counter-reactions, such as the suspension of gas and oil to countries in Eastern Europe. Nevertheless, the EU announced its decision to postpone talks on the revision of the Partnership and Cooperation Agreement (PCA) until Russia had fully withdrawn its troops from Georgia. In addition, it agreed to boost its financial contribution for the reconstruction of Georgia, as well as to have a "presence" in the region, whose military or policing role was not specified. EU leaders also decided to accelerate the discussion on the Eastern Partnership, which, following a proposal by Sweden and Poland in response to the French project of a Mediterranean Union, was scheduled to take place in mid-2009. The European Commission was in fact invited to present a detailed proposal before the end of 2008. ${ }^{23}$ Taking credit for this compromise, 
Berlusconi eloquently stated: "The Cold War has been avoided. Everyone now knows that the clock cannot be turned back and that we need to preserve the dialogue with Russia that we have developed over the last years." 24

The role that Italy played within the EU received mixed evaluations. While Putin praised it, Georgia criticized it, especially after Berlusconi called the Georgian intervention in South Ossetia "a serious provocation" that justified the Russian reaction. ${ }^{25}$ In his visit to Georgia, Frattini said that there were no shortcuts for Georgian admission to NATO and that, in an international conference on the South Caucasus to be organized in Rome, a package of measures would be adopted to support the "European vocation" of Georgia. The answer from the Georgian authorities was skeptical; they even rejected the idea of holding the conference in Rome. ${ }^{26}$ Among European leaders, Italy's position was singled out as being too close to Russia. For instance, a public statement by the Polish prime minister, Donald Tusk, is self-explanatory: "There are politicians, also in Europe, who would prefer empty conclusions because of their intensive bilateral relations with Russia." 27 The stance taken by Italy puzzled also the Bush administration. When Cheney visited Italy in early September, strains between the two governments became more visible. In the joint conference, Cheney criticized Russia, whereas Berlusconi remained silent. Concerns within the Bush administration were also raised about Italy's upcoming presidency of the G8 in 2009. The words of a diplomat from an Eastern European country best represent the view of various European states and that of the US: "Italy is Russia's Trojan horse in Europe." ${ }^{8}$

On 8 September, the EU's troika-Sarkozy, Javier Solana, and José Manuel Barroso-met with Medvedev and then with Saakashvili. Russia accepted that its troops would be replaced by EU observers, who, together with the staff of the Organization for Security and Co-operation in Europe (OSCE), would be in charge of monitoring the new agreement. Russia agreed to pull out from Georgia (with the exception of South Ossetia and Abkhazia) within 10 days of the deployment of the EU mission and to dismantle all checkpoints in Georgia within a week. The EU promised that if Russia maintained its pledge, discussions for the new PCA would be resumed. On 15 September, the EU's Council of Foreign Ministers approved a European Union Monitoring Mission (EUMM) to Georgia. The mission, to last one year, would be in charge of overseeing the full application of the six-point agreement and its follow-up, including the withdrawal of Russian troops, the normalization of civil governance, and the facilitation of contacts between the parties. With about 250-300 people coming from 20 member states, a number higher than initially expected, the EUMM 
was declared operational on 1 October. This was "the fastest deployment that the EU has ever undertaken," Solana stated when visiting the area. ${ }^{29}$ Meanwhile, following the full withdrawal of Russian troops from the buffer zone located in Georgia proper, European leaders started to discuss the resumption of the talks for the new PCA. Unsurprisingly, Italy was among the countries that called for a normalization of the EU's relations with Russia.

\section{Domestic Politics and Foreign Policy}

At the beginning of the 1990s, the collapse of the Italian party system that characterized the post-war period and the introduction of a quasi-majoritarian system generated two heterogeneous coalitions that, between 1994 and 2006, have alternated being in power. The new structure proved to be an imperfect bipolar system-fragmented, polarized, and often incapable of producing a bipartisan consensus on foreign policy.$^{30}$ Furthermore, the urgency to win the elections meant forming coalitions that were not very homogeneous and could easily be threatened by smaller parties. Paradoxically, on certain occasions the ruling coalition received more support from the opposition than from its own majority. The conclusion seemed clear, as noted by an acute analyst: "Unless the party system is simplified and political institutions are reformed ... no long-term improvement is in sight. It, therefore, seems that ... the divisiveness of the Italian political system still constrains the ability of the country to develop a successful foreign policy." 31

The general elections held in April 2008 not only saw the return of Berlusconi to power, but also marked a radical simplification of Italian politics. First, the number of parties with representation in Parliament was radically reduced: two from the center-right, two from the center-left, and one from the center. Second, the radical left failed to win any seats in Parliament. Third, a much more straightforward and clear-cut role for both the government and the opposition emerged. Obviously, the outcome of the elections was the result of a number of situations and events that had occurred during the previous two years: the negative perception of the Prodi government, which conditioned the performance of the center-left in the elections; the formation of the Partito Democratico (PD) and its decision to run the election in coalition with only one other party, the Italia dei Valori (IdV); and the formation of a new party on the center-right, the Popolo della Libertà (PdL), which ran in coalition with the Lega Nord (LN). Berlusconi appointed his cabinet in early May 2008, assigning the key posts to his most long-standing friends. A clear message was sent that the prime 
minister wanted a commanding role. ${ }^{32}$ This was also the case with the appointment of Frattini, who left the role of European commissioner to take up his new task as minister of foreign affairs.

The first test to assess the impact of the new political system on foreign policy was the war in Georgia. In this case, Italy achieved a bipartisan consensus, at least between its two major parties. This is, however, more a consequence of the fact that the PD-or better, the left-wing component within it-had previously pursued a pro-Russia policy. While during the Cold War the relationship with the Soviet Union was a contentious issue for political parties, in the Second Republic "one of the things that Italians politicians agree on is the importance of Italy's special entente with Russia." 33 A symbol of the shared conciliatory approach on the war in Georgia was the proposal for a peace conference to be held in Rome that was promoted by both the PD's Piero Fassino, the "shadow cabinet" minister of foreign affairs, and Frattini. Interestingly, in a joint piece published in Corriere della Sera, Filippo Andreatta, an astute observer of Italy's foreign policy very close to the centrist component of the $\mathrm{PD}$, and Pierferdinando Casini, the leader of the centrist Unione di Centro (UdC), criticized the PD for failing to take a tougher stance on Russia and to censure Berlusconi for his superficial and personalistic conduct in foreign policy. ${ }^{34}$ Fassino wrote a defensive answer, arguing that the views of the PD accidentally coincided with those of Berlusconi: "It is no doubt annoying that Berlusconi attempts to mix in his propaganda boasts and his opaque personal relations with Putin. But the PD is not to blame for this, as it needs to exercise its opposition role first and foremost for the good of Italy and Europe."35

The pro-Russia policy of the center-right government and the main party of the opposition was criticized more directly by some opposition parties - the UdC and the IdV, but also the Italian Radicals-and less directly by the radical left. To be precise, both the Partito dei Comunisti Italiani (PdCI) and Rifondazione Comunista (RC) pointed to the proposal to extend NATO membership to Georgia and Ukraine and to the recognition of Kosovo, both sponsored by the US, as the key factors in breaking the equilibrium in the region. In this sense, their support for the independence of South Ossetia and Abkhazia was a natural consequence of the decision to recognize Kosovo. Some friction also occurred between the PdL and the Lega Nord, which saw in Georgia a "sister nation," to be protected in the name of the independence of its people. Minister Roberto Calderoli was quoted as saying: "We stand with the people, not with the tanks." ${ }^{36}$ These divisions may remind us of the various disagreements that occurred during the center-left government, threatening the stability of the government itself. However, 
the difference between the two cases is substantial and is linked to party identity. In the case of the Lega Nord, foreign policy is not a vital issue because its identity is constituted by federalism. Its heterodox positions on Europe during the 2001-2006 center-right government and on the war in Georgia in 2008 did not put the stability of the coalition in jeopardy. It was somewhat easy for Berlusconi to offer "side payments" to the LN in order to block dissent. For the radical left, on the other hand, foreign policy is a salient issue, and pacifism (and often pure anti-Americanism) is the core of its identity. The margin of maneuver for Prodi was rather limited, and the only tools available were the threat of a political crisis and the use of the vote of confidence, which worked in June 2006 but failed in February 2007.37

\section{The Choice between Atlanticism and Europeanism}

As mentioned earlier, two heterogeneous coalitions have alternated in power between 1994 and 2006. Seen from a foreign policy perspective, the two coalitions held different views, especially with regard to the balance between Atlanticism and Europeanism, the two traditional lodestars of Italy's foreign policy. In general terms, the center-left coalition favored the European circle, entailing a strong but pragmatic commitment to a more integrated Europe and a more open attitude toward the Arab world. The center-right coalition placed more emphasis on the Atlantic circle, calling for a close relationship with the US and a lukewarm attitude toward the Arab world. When the centerright won the elections in April 2008, the thoughts in Europe went immediately to the previous Berlusconi government's attitudes toward Europe and more generally to its behavior in foreign policy. A large number of observers argued that Berlusconi was the first prime minister to invert Italy's traditional priorities in foreign policy by placing the United States at the top of his agenda and showing little enthusiasm for the European Union. As a consequence of these attitudes, Italy was excluded from a number of meetings and initiatives regarding the future of Europe and its role on the world stage. ${ }^{38}$

A few initial decisions seemed to confirm that Berlusconi's fourth government would be an "awkward" member state. First, the government's legislation on internal security, which led to discrimination against the Roma communities living in Italy and the introduction of the new criminal condition of illegal immigration, raised concerns in Europe about the protection of human rights. Second, the threat to boycott EU meetings where no working documents were available in Italian, conceived as a battle in defense of the Italian interest, was perceived as 
an indirect criticism of a "bureaucratic Europe." Third, the decision to save Alitalia and support Italian businesses was perceived as a violation of the EU's rules on state aid. After these initial skirmishes, a symbolic change came in August 2008 when the Italian Parliament adopted quickly and unanimously the Treaty of Lisbon, including the positive vote of the traditionally Euro-skeptical LN. ${ }^{39}$ The positions taken by the Berlusconi government regarding the war in Georgia seemed to confirm the changed attitude toward the European Union.

A closer look at the international context, however, shows that Berlusconi was constrained in his choices. When he took power in May 2008, the world looked different from 2001. First, a new generation of political leaders had emerged in Europe: Sarkozy and Angela Merkel had replaced Jacques Chirac and Gerhard Schröder, with whom Berlusconi did not have good relationships. Second, President Bush was at the conclusion of his second term. The Republican candidate for the US presidency, John McCain, whom he supported, was lagging behind in the polls vis-à-vis the Democratic candidate, Barack Obama. Berlusconi knew that should Obama win the election, he could no longer rely on a preferential route with the US. Paradoxically, his views on Russia were closer to those of Obama, who, during the Georgian war, took a balanced approach. McCain, by contrast, violently attacked Russia, calling for its expulsion from the G8. Third, the relations between Russia and the US, excellent in 2001, had progressively deteriorated. The ideal world in which he could be seen as the best friend in the European Union for both Russia and the US had put Berlusconi at odds with various countries in Western Europe. The only thing that had not changed was Putin's role in Russian politics. It is therefore not surprising that less than a week after the April 2008 elections, Berlusconi and Putin met in Berlusconi's villa in Sardinia. This was not an official visit, but the two had discussions about common projects in the gas and oil sectors and a new collaboration in the aviation sector-Aeroflot was a potential buyer of the Italian government's stakes in Alitalia. ${ }^{40}$

The alleged new Europeanist vision of the Berlusconi government, therefore, needs some qualifications. On the one hand, the support for a common foreign policy during the Georgian war was not ideological (i.e., to strengthen the EU's role in the international arena) but pragmatic, an accidental coincidence between Italy's economic interests and the mediation conducted by Sarkozy. On the other hand, in various cases related to the EU's external relations, the Berlusconi government did not hesitate to take an anti-EU stance when Italy's economic interests risked being compromised. First, in the environment field, it seriously questioned the commitment that the EU had made on climate change, claiming that the EU's ambitious agenda had a negative impact 
on Italy's business sector, especially in a time of economic slowdown. Second, in trade policy, it threatened to block the common position in the negotiations of the Doha Development Agenda in order to protect the national agricultural sector, especially in northern Italy, a matter of much interest to the Lega Nord. Third, the decision to introduce further cuts to the budget for international development undermined efforts that the EU was making toward achieving the UN's ambitious target of committing 0.7 percent of gross national product toward official development assistance for developing countries.

\section{Conclusion}

Since the end of the Cold War, two themes recur in the debate on Italy's foreign policy: the balance between Atlanticism and Europeanism and the impact of domestic politics on foreign policy. The war in Georgia has offered a litmus test to assess the line of the new Berlusconi government. While between 2001 and 2006 the Atlantic circle was favored, a number of choices in 2008 seemed to indicate a new trend. Berlusconi understood that within the new international context-the end of the Bush regime, the emergence of new leaders in Western Europe-the pursuit of Italy's national interest would not necessarily involve a special relationship with the US. The choice for Europe in the case of the Georgian war, however, was driven by pragmatism, the best way to protect Italy's economic interest. As for the link between domestic politics and foreign policy, a bipartisan consensus between the two largest parties was achieved. However, this was not a consequence of the simplified political system introduced by the April 2008 elections. Rather, it was due to the fact that both the PD and the PdL had carried out a pro-Russia policy since the end of the Cold War. Nevertheless, differences between the parties have not ceased to exist, confirming that domestic politics is still the variable that is central to understanding the contribution that Italy makes to the creation of a coherent external policy of the European Union and, more generally, the role that it wants to play in the international arena. 


\section{Notes}

1. In addition to Abkhazia and South Ossetia, the other two separatist states are the Pridnestrovskaya Moldovskaya Respublika (PMR) within Moldova and the Republic of Nagorno-Karabakh (NKR) within Azerbaijan. These entities are referred to variously as de facto states, quasi-states, self-declared states, unrecognized states, and separatist states.

2. On Georgia and the South Caucasus, see D. Lynch, "Separatist States and PostSoviet Conflicts," International Affairs 78, no. 4 (2002): 831-848; P. Kolstø and H. Blakkisrud, "Living with Non-recognition: State- and Nation-building in South Caucasian Quasi-states," Europe-Asia Studies 60, no. 3 (2008): 483-509; C. King, "The Benefits of Ethnic War: Understanding Eurasia's Unrecognized States," World Politics 53 (2001): 524-552; B. Coppieters, "The Politicisation and Securitisation of Ethnicity: The Case of the Southern Caucasus," Civil Wars 4, no. 4 (2001): 73-94; N. Tocci, "The EU and Conflict Resolution in Turkey and Georgia: Hindering EU Potential Through the Political Management of Contractual Relations," Journal of Common Market Studies 46, no. 4 (2008): 875-897.

3. B. Coppieters and R. Legvold, eds., Statehood and Security: Georgia after the Rose Revolution (Boston: MIT Press, 2005).

4. R. Gachechiladze, "Geopolitics in the South Caucasus: Local and External Players,” Geopolitics 7, no. 1 (2002): 113-138.

5. N. Tocci, The EU and Conflict Resolution: Promoting Peace in the Backyard (London and New York: Routledge, 2007): 128-129.

6. C. Collina, "A Bridge in Times of Confrontation: Italy and Russia in the Context of EU and NATO Enlargements," Journal of Modern Italian Studies 13, no. 1 (2008): 25-40; S. Giusti, "The Ambiguous Effects of the Rome-Moscow Bipartisan Axis on the EU Policy toward Russia," Italian Foreign Policy, no. 9 (2008), http://www.foreignpolicy.it.

7. O. Croci, "Much Ado about Little: The Foreign Policy of the Second Berlusconi Government," Modern Italy 10, no. 1 (2005): 59-74.

8. F. Andreatta and E. Brighi, "The Berlusconi Government's Foreign Policy: The First 18 Months," in Italian Politics: The Second Berlusconi Government, ed. J. Blondel and P. Segatti (New York: Berghahn Books, 2003), 221-236; S. Romano, "Berlusconi's Foreign Policy: Inverting Traditional Priorities," International Spectator 41, no. 2 (2006): 101-107; E. Brighi, “'One Man Alone?’ A Longue Durée Approach to Italy's Foreign Policy under Berlusconi,” Government and Opposition 41, no. 2 (2006): 278-297.

9. Collina, "A Bridge in Times of Confrontation," 30.

10. S. Romano, "Berlusconi’s Foreign Policy," 3. Roberto Aliboni argues that Berlusconi's support of bringing Russia into the West reflected "a realistic and pragmatic, essentially reductive, view of the evolution of the grand multilateral coalitions of the West put together during the Cold War. With the end of the East-West confrontation, these coalitions have lost their cohesion and, in a world in which international cooperation is less ideological and more flexible and national and cultural identities tend to re-emerge, are destined to be weakened and trivialized. Berlusconi's inclination can't help but reflect such trivialization." See R. Aliboni, "Neo-Nationalism and Neo-Atlanticism in Italian Foreign Policy," International Spectator 38, no. 1 (2003): 81-90, here 88.

11. R. Allison, M. Light, and S. White, Putin's Russia and the Enlarged Europe (Oxford: Blackwell, 2006). 
12. F. Morata, "The Italian Presidency of the European Union: An 'Abnormal' Semester?" in Italian Politics: Italy between Europeanization and Domestic Politics, ed. S. Fabbrini and V. Della Sala (New York: Berghahn Books, 2004), 115-132.

13. Collina, "A Bridge in Times of Confrontation"; Giusti, "The Ambiguous Effects."

14. O. Croci, "The Second Prodi Government and Italian Foreign Policy: New and Improved or the Same Wrapped Up Differently?" Modern Italy 13, no. 3 (2008): 291-303, here 300. On the foreign policy of the second Prodi government, see also E. Brighi, "How to Change Your Foreign Policy in 100 Days: A New Course for the New Prodi Government?” International Spectator 42, no. 1 (2007): 129-140.

15. S. Cornell, "War in Georgia, Jitters All Around," Current History 107, no. 711 (2008): 307-314.

16. A. Ward, Financial Times, 13 August 2008.

17. European Report, 1 September 2008.

18. R. Anderson, Financial Times, 12 August 2008; P. Hollinger, B. Benoit, and S. Pignal, Financial Times, 12 August 2008.

19. A. Rampino, La Stampa, 11 August 2008.

20. European Voice, 13 August 2008. The peace plan was endorsed by an emergency meeting of the EU's foreign ministers, held in Brussels on 13 August.

21. Following the recognition of the two regions, the foreign ministers of the G7, who in 1997 had invited Russia to join their ranks, due to its rising profile in world affairs, issued an unprecedented statement: "We ... condemn the action of our fellow G8 member ... Russia's decision has called into question its commitment to peace and security in the Caucasus." See J. Blitz and S. Wagstyl, Financial Times, 28 August 2008. Interestingly, a European diplomat was quoted as saying: "The Italians have clearly been dragging their heels on the G7 action of recent days. The statement that was issued by the G7 shows that they have come on board. But it is hard to believe that Italy would accept a major break with Russia ahead of next year's summit." See J. Blitz and D. Dombey, Financial Times, 30 August 2008.

22. European Report, 27 August 2008.

23. European Report, 9 September 2008; European Voice, 1 September and 4 September 2008.

24. G. Pelosi, Il Sole 24 Ore, 2 September 2008.

25. Ibid.

26. G. Gallo, Corriere della Sera, 4 September 2008; C. Marroni, Il Sole 24 Ore, 4 September 2008.

27. S. Rotella and A. Sicakyuz, Los Angeles Times, 2 September 2008.

28. G. Dinmore, Financial Times, 10 September 2008.

29. European Report, 16 September, 23 September, and 3 October 2008.

30. For an overview of Italy's foreign policy since the end of the Cold War, see M. Carbone, "The Domestic Dimension of Italy's Foreign and Development Policies," West European Politics 30, no. 4 (2007): 903-923.

31. F. Andreatta, "Italian Foreign Policy: Domestic Politics, International Requirements and the European Dimension," Journal of European Integration 30, no. 1 (2008): 169-182, here 170.

32. M. Carbone and J. Newell, "Toward the End of a Long Transition? Bipolarity and Instability in Italy's Changing Political System,” Politics 28, no. 3 (2008): $138-149$.

33. S. Giusti, "Italy's Russian Gambit May Let Moscow Divide the EU and Rule," Europe's World (Autumn 2007). 
34. F. Andreatta and P. F. Casini, Corriere della Sera, 6 September 2008.

35. P. Fassino, Corriere della Sera, 8 September 2008.

36. S. Cappellini, Il Riformista, 12 August 2008.

37. Carbone, "The Domestic Dimension."

38. On this issue, see L. S. Rossi, "New Trends in Italy's European Policy," International Spectator 37, no. 1 (2002): 97-106; P. Ignazi, "Al di là dell'Atlantico, al di qua dell'Europa: Dove va la politica estera italiana," Il Mulino, no. 2 (2004): 267-276; S. Romano, "Berlusconi’s Foreign Policy." Croci, by contrast, argues that this may be an exaggeration and that, at most, the Berlusconi government did not have the "fideistic attitude that characterized some of its predecessors." See Croci, "Much Ado about Little," 71.

39. L. Fioramonti and S. Lucarelli, "More of the Same? Berlusconi's Government and Europe,” Italian Foreign Policy, no. 10 (2008), http://www.foreignpolicy.it.

40. Giusti, "The Ambiguous Effects." 